\title{
In-vitro Susceptibility Profile of Pseudomonas aeruginosa to Selected Medicinal Plants Obtained from University of Calabar Farm, Nigeria
}

\author{
Iniobong E. Andy ${ }^{a}$, Ekomobong A. Okpo ${ }^{a^{*}}$, Christiana E. Ubengama ${ }^{a}$ \\ ${ }^{a}$ Department of Microbiology, Faculty of Biological Sciences, University of Calabar, P.M.B. 1115, \\ Calabar, Cross River State, Nigeria.
}

Authors' contributions

This work was carried out in collaboration among all authors. All authors read and approved the final manuscript.

Article Information

DOI: $10.9734 / A R R B / 2022 / v 37 i 130481$

Open Peer Review History: This journal follows the Advanced Open Peer Review policy. Identity of the Reviewers, Editor(s) and additional Reviewers, peer review comments, different versions of the manuscript, comments of the editors, etc are available here: https://www.sdiarticle5.com/review-history/83352

Original Research Article

Received 12 November 2021

Accepted 25 January 2022

Published 27 January 2022

\begin{abstract}
Antibiotic resistance represents the greatest challenges to global health. Strategies to curb the menace of antibiotic resistance include researching for new antimicrobials from plants. This study is aimed at determine the in-vitro susceptibility of Pseudomonas aeruginosa to Chromolaena odorata, Jatropha tanjorensis, Ocimum gratissimum, Vernonia amydalina, Hibiscus sabdariffa and Aloe barbadensis obtained within University of Calabar farm. All the test carried out were performed according to standard microbiological procedure. Ethanol was used for extraction of Phytochemicals and were purified using column chromatography. In-vitro susceptibility of selected plants against $P$. aeruginosa was in the order $C$. odorata $>$ J. tanjorensis $>0$. gratissimum $>H$. sabdariffa $>V$. amydalina $>A$. barbadensis (Aloe vera). The result revealed that the leaves of $C$. odorata had the highest antimicrobial effect against $P$. aeruginosa. The first column of all the plant extracts showed no antimicrobial activity. MIC of C. odorata, J. tanjorensis, $O$. gratissimum and $H$. sabdariffa were observed in $10^{-7}, 10^{-6}, 10^{-5}$ and $10^{-4}$ dilution respectively. Statistical analysis between the zone of inhibitions and layers of column chromatography was significant $(<0.05)$. Ethanol extract and the third column of Chromolaena odorata, Jatropha tanjorensis, Ocimum gratissimum have great potential antibacterial activity against $P$. aeruginosa.
\end{abstract}


Keywords: Medicinal; extract; plant; pseudomonas aeruginosa.

\section{INTRODUCTION}

Medicinal plants have been used for centuries to treat diseases in humans and animals [1]. This is due to the therapeutic potentials of their phytochemicals. Some of these phytochemicals exhibit a wide range of actions on pathogenic organisms [2]. The antimicrobial potential of these phytochemicals makes it a unique substance that can be used to initiate a bacteriostatic or bacteriocidal action on bacteria [3]. Phytochemicals have also been known to have some great antioxidant potentials which is of great interest as a result of their health benefits to humans [4]. Phytochemicals which include carotenoids, phytosterols, limonoids, polyphenol (i.e flavonoids, isoflavonoids anthocyanidins), Glucosinolates, phytoestrogen, terpennoids (isoprenoids), fibers, polysaccharides and saponins have been reported to have great health impact.

Flavonoids are the largest and most studied group of phytochemicals [4]. Flavonoids have been shown to have therapeutic effect as antihypertensive and antirheumatic as well as antimicrobial [3]. Glycoside have been used as a stimulant in cases of cardiac failure and disease [5]. Alkaloids can act as an antibacterial agent, anti-inflammatory, analgesic, hyporotic, local anesthetic, psychotropic and anti-tumor activity and many others. It also serves as stimulant.

Tannin is also another phytochemical that has great potential in promoting wound healing [6]. Moreso, tannin can be use as astringents against diarrhoea and as antioxidant, antiseptic and homeostatic pharmaceutical [7]. Terpenoid also refers to as isoprenoids is a naturally occurring organic chemical present in plant. It is derived from 5-carbon compound isoprene and isoprene polymer called terpenes. Terpernoid derived from plants are used for their aromatic qualities and play a very important role in traditional herbal remedies. It can also be used as antimalarial, antimicrobial antiulcer $[8,9]$.

Pseudomonas aeruginosa is a gram-negative bacterium that has an inherent (innate) resistant to many commonly used antibiotics such as ciprofloxacin, tobramycin and imipenem, its fast rate of developing resistant to new antibiotics has been a problem to health sector $[10,11]$ Through $P$. aeruginosa normally pathogenic when introduce to areas devoid of normal immune defense, its resistance ability makes it a major pathogen $[12,13]$. Thus, this study sought to find out an alternative for treatment of infections caused by Pseudomonas aeruginosa.

\section{MATERIALS AND METHODS}

\subsection{Sample Collection}

Stock culture of Pseudomonas aeruginosa was obtained from University of Calabar teaching hospital culture collection center. The isolates was taken to the microbiology laboratory for further analysis.

\subsection{Identification of the Isolate}

After 24 hours of incubation, Gram staining was carried out in other to confirm the suspected isolates as gram negative rods. The colonies formed were examined microscopically. Different biochemical test were employed for the presumptive identification of the isolates.

\subsection{Plant Collection and Preparation of Plant Extract}

Six plant species (Hibiscus sabdariffa, Chromolaena odorata, Jatropha tanjorensis, Aloe vera, Vernonia amygdalina and Ocimum gratissimum) were collected within University of Calabar farm.

The leaves of the plant were removed from the plant, washed and then dried under room temperature. The leaves of the plant were crush into powdery form. $100 \mathrm{~g}$ of dried powdered of each tested plants were extracted separately by maceration several times with ethanol (95\%) as the solvent.

\subsection{Purification of Plant Extract using Column Chromatography}

Column chromatography was use in purification of the plant extracts particularly the gravity column chromatography since the solvent was allowed to flow down the column by gravity without been forced by pressure pump. The solid phase used was silica gel and alumina.

Pieces of wire was used to add a pug of cotton to the bottom of the column, so that the silica will not fall out of the column. However, too much 
cotton or cotton packed too tightly will prevent the eluent from dripping at an acceptable rate.

The column was clamped to a tripod stand. Firstly, the column was filled up to $1 / 3$ with silica gel and the alumina was filled immediately after the silica gel. A space was left on top of the column for the eluent (solvent). The eluent was drained from the column until no solvent remains above the surface of the alumina. Using a Pasteur pipet, the extracts was carefully added to the column. Eluent was added to the column to ensure that no sample remain above the surface of the stationary phase (alumina). Three different fractions were collected into separate sample bottle for further analysis.

\subsection{Susceptibility Testing}

Two techniques (Disk diffusion and tube dilution method) were used to carry out susceptibility testing of the six selected medicinal plant extracts against $P$ seudomonas aeruginosa.

\subsection{Determination of Minimum Inhibitory Concentrations}

This was determined using tube dilution as described by Nwachukwu et al. [14]. The plant extracts with a better inhibition zone were selected and used for MIC test.

\subsection{Statistical Analysis}

Statistical analysis was carried out using Microsoft Excel (2007). Data obtained from the inhibition zone of ethanolic extracts and the different column of column chromatography were analyzed using regression analysis and values for $\mathrm{P}<0.05$ were considered as statistically significant

\section{RESULTS}

The morphologically characteristics of the isolates were recorded followed by a series of biochemical test as presented in Table 1.

Invitro susceptibility testing was performed on Pseudomonas aeruginosa species against the six medicinal plants using disc diffusion technique. Their various zones of inhibition were measured as shown in Table 2.

The result shows that chromolaena odorata, Jatropha tanjorensis and Ocimum gratissimum exhibited antibacterial activity on the Pseudomonas aeruginosa isolate. While Vernonia amydalina and Aloe vera showed no antibacterial activity on the isolates. But for Hibiscus sabdariffa it shows little inhibition effect.

Table 1. Morphplogical and biochemical characteristics of Pseudomonas aeroginosa

\begin{tabular}{lll}
\hline Test & Observation & Inference \\
\hline Gram stain & Curve rode, which appear pink & Gram negative \\
Catalase & Formation of bubble & Positive \\
Oxidase & Colorless to dark blue color & Positive \\
Citrate & Green to blue & Positive \\
Sugar fermentation & No changes & Negative \\
Motility & diffused, hazy growths that spread throughout & Motile \\
& the medium rendering it slightly opaque & \\
Urease & Color medium remained yellowish & Negative \\
Methyl red & Red & Positive \\
Voges proskauer & Yellow & Negative \\
Hydrogen sulphide & No change & Negative \\
\hline
\end{tabular}

Table 2. Inhibition zones of the medicinal plants

\begin{tabular}{|c|c|c|c|c|c|}
\hline \multirow[b]{2}{*}{ Plants } & \multicolumn{5}{|c|}{ Zones of inhibition (mm) } \\
\hline & $\begin{array}{l}\text { Ethanol } \\
\text { extract }\end{array}$ & $\begin{array}{l}\text { First } \\
\text { (C1) }\end{array}$ & fraction & $\begin{array}{l}\text { Second } \\
\text { fraction(C2) }\end{array}$ & $\begin{array}{l}\text { Third fraction } \\
\text { (C3) }\end{array}$ \\
\hline chromolaena odorata & 25 & 7 & & 10 & 19 \\
\hline Jatropha tanjorensis & 23 & 5 & & 13 & 15 \\
\hline Vernonia amydalina & 4 & 0 & & 0 & 0 \\
\hline Ocimum gratissimum & 20 & 0 & & 5 & 10 \\
\hline Aloe barbadensis & 2 & 0 & & 0 & 0 \\
\hline Hibiscus sabdariffa & 11 & 3 & & 5 & 9 \\
\hline
\end{tabular}


The antibacterial screening for chromolaena odorata showed that the ethanol extract exerted antimicrobial activity on Pseudomonas aeruginosa with inhibition zone of $25 \mathrm{~mm}$, third fraction with inhibition zone of $19 \mathrm{~mm}$, second fraction with inhition zone of $10 \mathrm{~mm}$ and first fraction with inhibition zone of $7 \mathrm{~mm}$.

For Jatropha tanjorensi, ethanolic extract showed inhibition zone of $23 \mathrm{~mm}$, third fraction with inhibition zone of $15 \mathrm{~mm}$, second fraction with inhibition zone of $13 \mathrm{~mm}$ and first fraction of Jatropha tanjorensis showed inhibition zone of $5 \mathrm{~mm}$. The Vernonia amydalina and Aloe vera exhibited little or no antimicrobial activity. Ethanol extract of Vernonia amydalina showed inhibition zone of $4 \mathrm{~mm}$ while for Aloe vera, ethanol extract showed inhibitory zone of $2 \mathrm{~m}$. third fraction, second and first of both Vernonia amydalina and Aloe vera showed no zone of inhibition $(0 \mathrm{~mm})$.

Ocimum gratissimum ethanol extract showed inhibition zone of $20 \mathrm{~mm}$, third fraction with inhibition zone of $10 \mathrm{~mm}$ and second fraction and first fraction with inhibition zone of $5 \mathrm{~mm}$ and 0 $\mathrm{mm}$ respectively. Hibiscus sabdariffa ethanol extract demonstrated lowered antibacterial activity with inhibition zone of $11 \mathrm{~mm}$, third fraction with inhibition zone of $9 \mathrm{~mm}$, second fraction with inhibition zone of $5 \mathrm{~mm}$ and first fraction with inhibition zone of $3 \mathrm{~mm}$

Furthermore, antimicrobial activities of all the plants extracts are represented in the Fig. 1.

From the above figure, all the ethanolic' extracts shows antimicrobial activity. But chromolaena odorata shows highest antimicrobial activity followed by odorata, Jatropha tanjorensis, Ocimum gratissimum and Hibiscus sabdariffa. Ethanolic extracts of Vernonia amydalina and Aloe vera shows least antimicrobial activity.

Extracts that gave higher zones of inhibition were used for conducting MIC using Macro tube dilution method. The result is presented in Table 3.

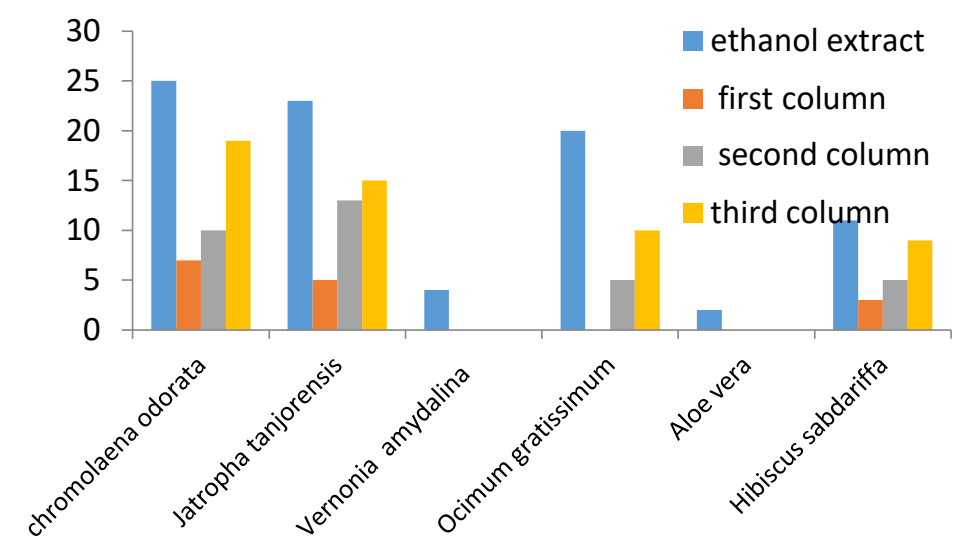

Fig. 1. Antibiogram study of the ethanol extracts and the three layers or columns of the chromatography

Table 3. Minimum inhibitory concentration

\begin{tabular}{ll}
\hline Plants ethanol extracts & Highest dilution factor that shows no tubidity \\
\hline chromolaena odorata, & $10^{-7}$ \\
Jatropha tanjorensis & $10^{-5}$ \\
Ocimum gratissimum & $10^{-6}$ \\
Hibiscus sabdariffa & $10^{-4}$ \\
\hline
\end{tabular}




\subsection{Statistical Analysis}

At $95 \%$ confidence interval or 0.05 significance level. p-value of the calculated was observed to be 0.0274 which implies that $p<0.05$. Since $\mathrm{p}<0.05$, the null hypothesis was rejected which stated that there is no correlation or there is no association between the independent and the dependent variable. Therefore, this variable is statistically significance.

\section{DISCUSSION}

In this study, Chromolaena odorata, Jatropha tanjorensis, Ocimum gratissimum, Vernonia amydalina, Aloe vera and Hibiscus sabdariffa were used to perform antimicrobial susceptibility test. Although leaf, stem and root are the three parts of plant and each has antimicrobial activity. However, the leaf of Chromolaena odorata, Jatropha tanjorensis, Ocimum gratissimum Vernonia amydalina, Aloe vera and flower of Hibiscus sabdariffa were used in this study. Similarly, there are various solvent that can be used in the extraction of plant, but ethanol was the only solvent that was used in the extraction process.

The result of this analysis showed that the leaves of Chromolaena odorata ethanol extract, first, second and third fraction exhibited high antimicrobial effect against Pseudomonas aeruginosa with the zones of inhibition ranging between $7.0 \mathrm{~mm}-25.0 \mathrm{~mm}$. This result is similar with the findings of Nurul et al., [15]; Nwachukwu et al., [14]; Mbajiuka et al., [16] and Srisuda et al., [17]. Furthermore, Srisuda ${ }^{18}$ also recorded that both ethanol and methanol solvents could extract antimicrobial compounds (flavonoids, flavones, polyphenols, terpenes and tannins) from the leaf of $C$. odorata.

Jatropha tanjorensis showed antimicrobial activity with the zones of inhibition ranging between $5 \mathrm{~mm}-23 \mathrm{~mm}$. This is similar to the result of a study carried out by Ogunnusi ${ }^{18}$ on the activity of leaf extracts of Jatropha tanjorensis and found out that it had activity against Pseudomonas aeruginosa. The actimicrobial activity of this plant is as a result of phytochemical constituents of the plant as Ogunnusi et al., [18] recorded that the plant extracts revealed the presence of saponins, alkaloids, tannins, cardiac glycosides and flavonoids and absence of phenols and phlobatannins.
Vernonia amydalina showed very little zone of inhibition ranging from $0 \mathrm{~mm}-4 \mathrm{~mm}$. Recently, Kolawole et al., [19] also reported that Pseudomonas aeroginosa was not susceptible to Vernonia amydalina and stated that the reason for this might be for the low amount of steroids, flavonoids, alkaloids and tannins in Vernonia amygdalina (bitter leaf). This also agreed with report of Nweze $[19,20]$.

Ocimum gratissimum showed antimicrobial activity with the exception of the first column obtained from column chromatograph. The ethanol extract, the third and second column exhibited zone of inhibition ranging between $5 \mathrm{~mm}-20 \mathrm{~mm}$. Kolawole et al., 2018 also stated that the higher presence of steroids, flavonoids, alkaloids and tannins in Ocimum gratissimum (scent leaf) than in Vernonia amygdalina (bitter leaf) could have been attributed to its higher antibacterial activity against the test organisms as this plant extract was found to be susceptible to Pseudomonas aeroginosa.

Priscilla et al., [21] recorded that Hibiscus sabdariffa inhibitor effect of the antimicrobial activity of the aqueous and ethanol extracts seems to have an effect on both Gram positive and Gram-negative bacteria and suggests the broad-spectrum nature of the plant against bacteria. In this study ethanol extract showed small inhibitory effect with the zone of clearance ranging between $3 \mathrm{~mm}-11 \mathrm{~mm}$. Gehan et al., [22]; Ifeanyi et al., [23] also recoded similar result, in their study Hibiscus sabdariffa showed lower antimicrobial activity with all the isolate of pseudomonas with inhibition zone ranging between $9.4 \mathrm{~mm}-10.8 \mathrm{~mm}$.

Results obtained from this study, indicated that the Aloe barbadensis extracts showed lower antimicrobial activity than the commercially available antibiotics used.

Generally, the first column of all the plant extracts obtained from the column chromatography showed little or no antimicrobial activity. The extent of antimicrobial activity between the various fractions and the ethanol extracts is in the order of: ethanol extract>third fraction $>$ Second fraction $>$ first fraction. This may be due to the fact that some phytochemicals constituents were washed during purification process by column chromatography. 1. Original Research Article 


\section{CONCLUSION}

The study has revealed that Chromolaena odorata, Jatropha tanjorensis, Ocimum gratissimum plant extract have good antibacterial properties thus a potential source of new drug for treating wound infections and other ailment caused by Pseudomonas aeruginosa. Although, $H$. sabdariffa also showed antimicrobial activity but lower than Chromolaena odorata, Jatropha tanjorensis, Ocimum gratissimum. In constrast, Vernonia amydalina and aloe vera show no antimicrobial activity.

It can be concluded from this research that, the crude ethanol extract and the third column of Chromolaena odorata, Jatropha tanjorensis, Ocimum gratissimum, showed the best antimicrobial activity against the isolate. This is followed by second and first column of the extracts. Therefore, they may be explored further in the field of human medicine for the production of antimicrobial agents which will significantly inhibit the growth of bacteria.

\section{COMPETING INTERESTS}

Authors have declared that no competing interests exist.

\section{REFERENCES}

1. Azwanida NN. A review on the extraction methods use in medicinal plants, principle, strength and limitation. Medicinal and Aromatic Plants. 2015;4(3):1-6.

2. Venugopal R, Liu RH. Phytochemicals in diets for breast cancer prevention: The importance of resveratrol and ursolic acid. Food Science. 2012;15: 35-41

3. Veerachari U, Bopaiah AK. Preliminary phytochemical evaluation of the leaf extract of five Cassia species. Journal of Chemical Pharmacology of Research. 2011;3(5):574-583.

4. Esseiett UA, Bala DN, Agbakahi JA. Pharmacognostic studies of the leaves and stem of Diodiascandens SW in Nigeria. Archives of Applied Science Research. 2010;2(5):124-128.

5. Taiwo A, Abidemi C, Oyedepo J, Adebayo B, Oluwadare, I., Agboto, D. Nutrient content and antinutritional factor in shea butter (Butryospermum parkii) leaves. African Journal of Biotechnology. 2009; 8(21):5888-5890.
6. Olajide O, Idowu D, Okolo S, Orishadipe A, Sunday T. Phytochemical and antioxidant properties of some Nigerian medicinal plants. American Journal of Scientific and Industrial Research. 2013;4(3):328- 332

7. Dolara P, Luceri C, De Filippo C, Femia AP, Giovannelli C, Carderni G. Red wine polyphenols influence carcinogens, intestinal microflora, oxidative damage and gene expression profiles of colonic mucosa in F344 rats. Mutation Research. 2005;591(1-2): 237-246.

8. Dolara N, Pichersky E, Gershanzon D. Plant Physioliology. Journal of Biochemistry of plant volatiles. 2004;135(4):1893-1902.

9. Joshi B, Sah GP, Basnet BB, Bhatt MR, Sharma D, Subedi K. Phytochemical extraction and antimicrobial properties of different medicinal plants: Ocimum santum (Tulsi), Eugenia caryophyllata (Clove), Achyranthes bidentata (Datiwan) and Azadirachta indica (Neem). Journal of Microbiology and Antimicrobials. 2011;3(1):1-7.

10. Cavallo JD, Hocquet D, Plesiat P, Fabre R, Roussel-Delvallez M. Susceptibility of Pseudomonas aeruginosa to antimicrobials,French multicentre hospital study. Journal of Antimicrobial Chemotherapy. 2007;59(5):1021-4

11. Pitt TL, Simpson AJ. Pseudomonas aeruginosa and Burkholderia spp. In: P.M. Hawkey, S.H. Gillespie, (Ed.). Principles and Practice of Clinical Bacteriology Chichester: John Wiley and Sons; 2006.

12. Geo FB, Karen CC, Janet SB, Stephen AM, Timothy AM. Jawetz Melnic and Aldeberg's Medical Microbiology. United State of America: McGraw Hill Press; 2013.

13. Brown PD, Izundu A. Antibiotic resistance in clinical isolates of Pseudomonas aeruginosa in Jamaica. Pan American Journal of Public Health. 2004;16(2):12513.

14. Nwachukwu I, Aliga C, Upabi CF, Ukogo I. In-Vitro Antibacterial Effect of Crude Extract of Chromolaena Odorata Leaves on Wound Isolates. Journal of Pharmacy and Biological Sciences. 2016;11(6):22783008.

15. Mbajiuka, C. S., Obeagu, E. I., Chude, C. N. Antimicrobial effects of Chromolaena odorata on some human pathogens. International Journal Current Microbiolology and Applied Science. 2014;3(3): 1006-1012. 
16. Srisuda HS, Piyaporn W, Niwat K, Sukhumaporn K. Antimicrobial Activity of Chromolaena odorata extracts against Bacterial Human Skin Infection. Modern Applied Science. 2016;10(2):159-171

17. Ogunnusi E, Tolulope A, Oyebode El, Adika AM. Antimicrobial activity of extracts from Jatropha gossypiifolia and Jatropha tanjorensis. Journal of Science. 2016;6(12): 515-520.

18. Kolawole S, Obueh $\mathrm{H}$, Ukachi A. Antibacterial Effect of Vernonia Amygdalina and Ocimum Gratissimum on Some Bacteria that Cause Opportunistic Infections in HIV/AIDS Patients. Journal of Nutritional Health \& Food Science. 2018:5:1-5

19. Nweze El, Okafor JI, Njoku O. Antimicrobial activities of methanolic extracts of Trema guineensis (Schumm and Thorn) and Morinda lucida Benth used in Nigerian. Biological Research. 2004; 2(1):39-46

20. Priscilla A, Naa A, Lovell A. Antimicrobial Activity of Hibiscus Sabdariffa Against Clinical Isolates of Bacteria. Review of Plants. 2014;3:1-5
21. Gehan MK, Ezzeldeen NA, Mostafa Y, Mishad El, Reham FE. Susceptibility Pattern of Pseudomonas aeroginosa Against Antimicrobial Agents and Some Plant Extracts with Focus on Its Prevalence in Different Sources. Global Veterinaria. 2011;6(1): 61-72

22. Ifeanyi OO, Reuben AUN, Uchenna ME, Evelyn UU. Phytochemical Analysis and in-vitro Antimicrobial Activities of Crude Extracts of Aloe barbadensis (Aloevera) Leaf on Microorganisms Isolated from Surgical Wound Patients at Nnamdi Azikiwe University Teaching Hospital (NAUTH), South-Eastern, Nigeria International Journal of Internal Medicine. 2016;5(1):1-7

23. Nurul HAK, Mamat AS, Effendy AWM, Hussin ZM, Iskandar CTNF, Hassan L, Dhaliwal GK, Yusoff R, Omar AR, Khan M. The antimicrobial effect of Chromolaena odorata extract on Grampositive bacteria. Animal health: a breakpoint in economic development?. Veterinary Association Malaysia Congress. 2004;13: 342-343

(C) 2022 Andy et al.; This is an Open Access article distributed under the terms of the Creative Commons Attribution License (http://creativecommons.org/licenses/by/4.0), which permits unrestricted use, distribution, and reproduction in any medium, provided the original work is properly cited.

The peer review history for this paper can be accessed here: https://www.sdiarticle5.com/review-history/83352 